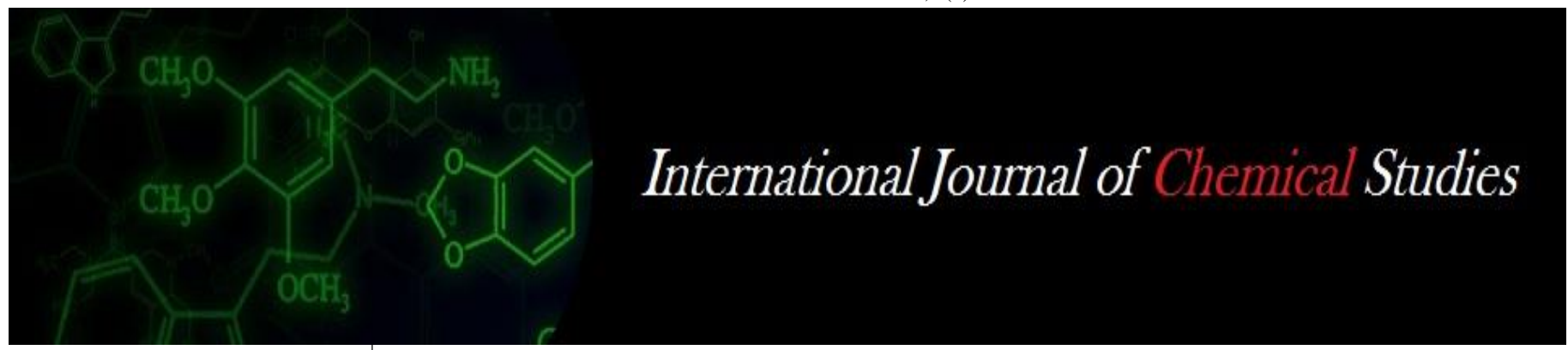

P-ISSN: 2349-8528

E-ISSN: 2321-4902

www.chemijournal.com

IJCS 2020; 8(2): 771-785

(C) 2020 IJCS

Received: 11-01-2020

Accepted: 15-02-2020

\section{RA Sharma}

Director, Mandsaur University,

Mandsaur, Madhya Pradesh,

India
Corresponding Author:

\section{RA Sharma}

Director, Mandsaur University,

Mandsaur, Madhya Pradesh,

India

\section{Soil health and land degradation related problems and remedial measures with special reference to central and peninsular India}

\section{RA Sharma}

DOI: https://doi.org/10.22271/chemi.2020.v8.i21.8861

\begin{abstract}
Land degradation in black soil regions of India (occurring between $8^{\circ} 45^{\prime}$ and $26^{\circ} 0^{\prime} \mathrm{N}$ latitude and $66^{\circ} 0$ and $83^{\circ} 45^{\prime} \mathrm{E}$ longitude spread over an area of $76.4 \mathrm{~m}$ ha constituting almost 22.2 per cent of total geographical area of India) is the continuous process for some inherent soil physicochemical and hydrological properties coupled with poor management. The soils in these regions occur on flat to varying degree of undulating topography and therefore water erosion accompanied by severe losses of essential plant nutrients are the serious problems even on flat topography. This emphasizes the need for effective conservation of land and water resources and their efficient utilization for enhancing crop productivity on sustainable basis. Appropriate cost effective conservation measures for land and water have been found effective in improving the land and water resources and thereby productivity of crops and live-stocks. Integrated watershed management is now considered as the best approach for sustainable protection, preservation and efficient utilization of all the natural resources particularly land and water and socio-economic resources. Present paper reviews land degradation status and various kinds of land uses and presents the technological options for managing them so that productivity of arable crops may be improved on sustainable basis.
\end{abstract}

Keywords: Soil health, degradation, remedial measures, special reference, peninsular

\section{Introduction}

Land degradation is a wide spread problem and has become a serious threat for sustainable agriculture. The task of feeding world population, expected to reach 9 billion people by 2050 , is a big challenge in view of wide spread degradation and increasing scarcity of land and water resources (FAO Report of 28 November, 2011, Rome), The State of the World's Land and Water Resources for Food and Agriculture (SOLAW) reported for the first time that 25 percent of the earth's lands are degraded. Different estimates indicate about 114 to $147 \mathrm{M}$ ha of degraded and waste lands belong to different categories in India. The state of Madhya Pradesh occupies $9.26 \%$ (30.83M ha) of nation's geographical area $(328.73 \mathrm{M}$ ha) of which $45.73 \%$ have been reported to be degraded and waste lands. The total area affected by water erosion (including open forest areas) in M.P. accounts for $13.47 \mathrm{M}$ ha (44\% of TGA). One of the major constraints that limit the productivity of crops in black clay soil regions is poor soil health. We, therefore, are left with no choice but to regenerate and rejuvenate and utilize the nature in a planned manner following a holistic watershed based approach aimed at optimizing the use of available natural resources (Land, water and vegetation).

\section{Soil health and its degradation?}

The soil organic system is the single most important parameter determining the soil health because of its profound impact on soil physical, chemical, and biological properties. Therefore, the concept of soil health, like that of human health, is not difficult to understand when the system is viewed as a whole. The challenge is to manage soils such that they are able to perform the various uses without degradation and also without harming the environment. Doran and Parkin (in Doran et al., 1994) ${ }^{[1]}$ defined soil quality (health) as "the capacity of a soil to function, within ecosystem and land use boundaries, to sustain biological productivity, maintain environmental quality, and promote plant and animal health". It is worth mentioning here that "soil health" and "soil quality" are essentially synonymous terms. 


\section{Characterization of soil health}

There are many different concepts of what constitutes soil health. Probably the most familiar concept of soil health would be as it relates to the growth of plants. The concept of soil health is location and land use dependant. The soil health has different meanings for a farmer, engineer, and other users, etc. There are some important soil properties that indicate soil health. These properties fall into three main categories: soil chemical properties, soil physical properties, and soil biological properties (Table 1). Different properties that constitute a healthy soil are not the same in all places and all situations.

Table 1: Commonly used indicators of soil health

\begin{tabular}{|c|c|c|}
\hline Chei & Physical Indicators & Biologic \\
\hline $\begin{array}{c}\mathrm{pH}, \text { Organic matter, } \\
\text { Total carbon, Total } \\
\text { nitrogen, Cation } \\
\text { exchange capacity, } \\
\text { Major and minor } \\
\text { nutrients, Electrical } \\
\text { conductivity, Heavy } \\
\text { metals and other } \\
\text { plant toxins }\end{array}$ & $\begin{array}{c}\text { Texture, Bulk } \\
\text { density, Penetration } \\
\text { resistance, } \\
\text { Aggregate stability, } \\
\text { Water holding } \\
\text { capacity, Infiltration } \\
\text { rate, Depth to } \\
\text { hardpan, Water table } \\
\text { depth, Porosity \& } \\
\text { Aeration, Erosive } \\
\text { potential }\end{array}$ & $\begin{array}{l}\text { Microbial biomass, } \\
\text { Earthworm population, } \\
\text { Nematode population, } \\
\text { Arthropod population, } \\
\text { Mycorrhizal fungi, } \\
\text { Respiration rate, Soil } \\
\text { enzyme activities, } \\
\text { Pollutants, } \\
\text { Detoxification, } \\
\text { decomposition rate }\end{array}$ \\
\hline
\end{tabular}

\section{Soil organic matter}

Enrichment of soil organic carbon (SOC) stocks through sequestration of atmospheric $\mathrm{CO}_{2}$ in agricultural soils is important because of its impacts on improving soil quality and agronomic production, and also for adaptation to and mitigation of climate change. SOC concentration can be increased by management practices that create a positive $\mathrm{C}$ budget ( $\mathrm{C}$ gains exceed the losses). Therefore, increase in SOC stock can result from:

1. Improved cropping systems.

2. Increased quantity of residues produced and retained.

3. Enhanced use efficiency of inputs such as $\mathrm{N}$ and water (Follett 2001).

Adoption of these and other BMPs can enhance SOC sequestration while improving soil quality and mitigating atmospheric $\mathrm{CO} 2$ enrichment. Observed that at least partial retention of the crop residues is necessary to maintaining soil quality in the rain-fed semiarid conditions. Verhulst and colleagues observed that most soil quality indicators (i.e., mean weight diameter, aggregate stability, water infiltration rate, soil moisture storage, microbial biomass carbon or $\mathrm{MBC}$, nutrient reserves) were lower with residue removal than with its retention. Although, the use of mineral fertilizers is important to increase productivity, hidden $\mathrm{C}$ costs of chemical fertilizers are high. Further, use of chemical fertilizers in rainfed cropping is meager because of the prohibitively high cost and low use efficiency under harsh climatic conditions. India produces about $185 \mathrm{Tg}\left(\mathrm{Tg}=\right.$ teragram, $10^{12} \mathrm{~g}=1$ million metric tons) of crop residues, of which about one-third is available for recycling on arable lands (Lal 2005; Deshpande et al. 2007). There are not enough nutrients recycled to support the growth of subsequent crops when low amounts of crop residues are applied. In these situations, a judicious use of inorganic fertilizers is also necessary to meet the nutrient requirements for increasing production of rain-fed crops. The rate of $\mathrm{C}$ addition from crop residues and manure must equal the rate of loss through decomposition, harvest and erosion. Residue mulches also conserve soil and water and increase the available water capacity of the post-rainy season crops. Aune and Lal (1995) reported that the threshold level of SOC for Vertisols is about $11 \mathrm{~g} \mathrm{~kg}^{-1}\left(19 \mathrm{~g} \mathrm{~kg}^{-1} \mathrm{SOM}\right)$. However, the research data on SOC management for Vertisols are limited. A survey of SOC concentration, conducted at 21 locations across rain-fed regions of tropical India and involving eight production systems, showed that these soils are low in SOC $\left(<5 \mathrm{~g} \mathrm{~kg}^{-1}\right)$ and in profile-based SOC stocks.

\section{Organic matter and soil physical properties}

SOM usually have a positive influence on soil health as the addition of organic materials to a soil can lead to a wide range of improved physical properties. Losses of SOM tend to have negative impacts. SOM is known to influence soil physical properties as it is related to aggregate formation and stability. SOM decomposition produces mucus-like "glues" that help create and stabilize soil aggregates which in turn improve water infiltration by creating large pore spaces. The combination of large aggregates and good infiltration makes a soil less erosion prone than similar soils with poor aggregation and infiltration.

Improved soil aggregation results in a increased water storage and aeration in the soil. Small pores within the aggregates are able to hold water through moderately dry periods. The large pores between aggregates allow for rapid drainage of water, followed by the movement of air into the large pores. Resistance to root penetration generally decreases with increasing SOM content and soil also becomes easier to plough because it requires less energy to pull tillage implements.

\section{Organic matter and soil chemical properties}

Besides being natural source of essential plant nutrients, soil organic matter helps releasing plant nutrients from soil and chemical fertilizers. Further, soils with adequate organic matter content do not need much application of chemical fertilizers and thus can save on fertilizer costs as well as help avoid some of the environmental problems that can arise from high levels of fertilizer use.

Some other important chemical properties affected by SOM are cation exchange capacity (CEC) and buffering capacity of soil. Soils with a high buffering capacity are more resistant to $\mathrm{pH}$ changes. The humus in SOM has a CEC of approximately $200-260 \mathrm{meq} / 100 \mathrm{~g}$ soil, which is high, compared to clay. Therefore, SOM increases overall soil CEC, and increases the ability of a soil to store essential nutrients in cationic form. High CEC makes fertilization more efficient, as cation nutrients that are not immediately used by crops can be stored in the soil for future use.

\section{Organic matter and soil ecosystem}

Being a source of energy, adequate SOM has a profound effect on the numbers, kinds, and diversity of organisms in the soil. The presence of such an ecosystem is particularly important because it includes decomposers-organisms that break down dead organic materials. Without the actions of decomposers, essential plant nutrients would not be released from SOM, organic "glues" important in soil structure would not be formed, and many of the important chemical and physical benefits of SOM would not be realized.

\section{Soil/Land degradation?}

Land degradation may be defined as any change in the land that reduces its condition or quality and hence its productivity. FAO's definition of degradation extends beyond soil and 
water degradation per se and includes an assessment of other aspects of affected ecosystems. Degradation of land leads to a degraded soil having so unfavorable physico-chemical and biological conditions which are unsuitable for agricultural production unless reclaimed. A soil may be degraded chemically, physically, biologically or combinations any of above referred parameters. All these properties are interdependent on each other. The term Land degradation can be applied differently across a wide range of scenarios. The ultimate results of land degradation of different degrees may be decreased productivity of the soils, loss of biodiversity, environmental pollution and enhanced vulnerability of the environment and ultimately poor economy and crisis in society.

\section{Causes of land degradation}

Land degradation may arise from human activities and habitation patterns, such as:

1. Soil erosion caused by wind and/or water.

2. Deterioration of the physical, chemical, and biological or economic properties of soil.

3. Long-term loss of natural vegetation.

Desertification is another type of the degradation of land in many areas which is caused primarily by human activities and climatic variations. Desertification does not refer to the expansion of existing deserts. It occurs because dry-land ecosystems, which cover one-third of the world's land area, are extremely vulnerable to over-exploitation and inappropriate land use. Poverty, political instability, deforestation, overgrazing, and bad irrigation practices can all undermine the land's fertility [http://www.fao.org/desertification/ default.asp/en]. Desertification is a type of land degradation which converts useful but arid lands to less useful desert. It is characterized by

1. Declining groundwater.

2. Increased erosion.

3. Disappearance of native vegetation.

Usual types of land degradation that have been known for centuries include water, wind and mechanical erosion, physical, chemical and biological degradation. Four other types of

degradation

[http://en.wikipedia.org/wiki/Land_degradation\#cite.note-6]

have emerged in the last 50 years are.

1. Pollution, often chemical, due to agricultural, industrial, mining or commercial activities.

2. Loss of arable land due to urban construction.

3. Artificial radioactivity, sometimes accidental.

4. Land-use constraints associated with armed conflicts.

Overall, 36 types of land degradation can be assessed.

The major causes of land degradation are abuse of lands regardless of its capability, deforestation, poor fertility management practices, overgrazing, faulty irrigation practices, over exploitation of ground water, soil and water pollution, urbanization and commercial developmental activities on good quality lands, ill planned mining, shrinking land holding size, exposure of naked soil after harvesting by heavy equipments, monoculture, destabilizing the local ecosystem, and (12) Dumping of non-biodegradable trash, such as plastics, etc.

\section{Land degradation status}

According to FAO report (Published on 28 November, 2011, Rome), the task of feeding a world population, expected to reach 9 billion people by 2050, is a big challenge in view of wide spread degradation and increasing scarcity of land and water resources. FAO estimates that by 2050, rising population and incomes will require a 70 percent increase in global food production. This equates to another one billion tons of cereals and 200 million tonnes of livestock products produced each year.

\section{World's status of degraded lands}

The State of the World's Land and Water Resources for Food and Agriculture

(SOLAW)

[http://www.fao.org/nr/solaw/solaw.home/en/] reported for the first time that 25 percent of the earth's lands are degraded. Fully one quarter are highly degraded. Another $8 \%$ are moderately degraded, $36 \%$ are stable or slightly degraded and $10 \%$ are ranked as "improving." The remaining shares of the earth's land surface are either bare (around $18 \%$ ) or covered by inland water bodies (around 2\%). These figures include all land types, not just farm land. Some 1.6 billion hectares of the world's best, most productive lands are currently used to grow crops. Parts of these land areas are being degraded through ill farming practices that result in water and wind erosion, the loss of organic matter, top soil compaction, salinization, soil pollution, and nutrient loss.

Wind erosion and water-induced soil erosion are prominent in arid and semi-arid regions. Dry lands, which cover about $41 \%$ of Earth's land surface, are home to more than $38 \%$ of the total global population of 6.5 billion. Severe land degradation is present on 10 to $20 \%$ of these lands, which are estimated to affect directly some 250 million people in the developing world.

A poverty trap: Some 40 percent of the world's degraded lands are found in areas with high poverty rates. Still, in a sign that degradation is a risk across all income groups, 30 percent of the world's degraded lands are in areas with moderate levels of poverty while 20 percent are in areas with low poverty rates.

\section{Land and water degradation status in India}

India has a total geographical area of $328.2 \mathrm{M}$ ha with a cultivated area of $141 \mathrm{M}$ ha. Land degradation is a continuous process which results due to Water erosion, Wind erosion, Chemical degradation, Physical degradation and due to mining and industrial wastes. Abuse or misuse of arable lands also causes severe degradation. A considerable area is either wastelands or degraded lands. A brief statistics of such lands and their uses have been summarized in the Tables 2 through 5 which are self-explanatory. The differences in total area under degraded lands (Tables 2 and 3 ) are mainly due to adoption of different approaches for the generation of maps. A harmonized classification system comprising wasteland classes and soil degradation has been prepared considering commonality/dissimilarity of classes, as given in Table 4.

Based on the area statistics presented in Table 5 a preliminary assessment has been made. As per this, the total area under degraded and wastelands in the country stands at $114.01 \mathrm{M}$ ha. The extent of area under water erosion is $23.62 \mathrm{M}$ ha, and under wind erosion is $8.89 \mathrm{M}$ ha. Chemical degradation comprises salinization/alkalization and acidification $(<5.5$ 
$\mathrm{pH})$. Area under salt-affected soils is $6.73 \mathrm{M}$ ha and under acid soils is $16.03 \mathrm{M}$ ha. Vegetal degradation with water erosion includes land with/without scrub, degraded forestscrub dominated, agricultural land inside notified forest, degraded pasture/grazing land, degraded land under plantations and abandoned and current shifting cultivation areas of wasteland map, prepared by the NRSA. Other categories include mining and industrial waste, barren rocky/stony waste and snow-covered/ice caps, occupying 12.17 $\mathrm{M}$ ha (Table 5).

Table 2: NBSS \&LUP soil degradation classes, derived from 1:250,000 soil map (1985-1995)

\begin{tabular}{|c|c|c|c|c|c|}
\hline Wasteland class & Area (M ha) & Percent & Wasteland class & Area (M ha) & Percent \\
\hline Gullied/ravines land & 2.06 & 0.65 & Degraded land under plantation & 0.58 & 0.18 \\
\hline Land with/without scrub & 19.40 & 6.13 & Sandy area & 5.00 & 1.58 \\
\hline Waterlogged/marshy land & 1.66 & 0.52 & Mining/ industrial wasteland & 0.12 & 0.04 \\
\hline Land affected by salinity & 2.04 & 0.65 & Barren rock y/stony/sheet rock & 6.46 & 2.04 \\
\hline Shifting cultivation area & 3.51 & 1.11 & Steep sloping area & 0.77 & 0.24 \\
\hline Degraded notified forest land & 14.07 & 4.44 & Snow covered/glacial area & 5.58 & 1.76 \\
\hline Degraded pastures land & 2.60 & 0.82 & Total & 63.85 & 20.16 \\
\hline
\end{tabular}

(Source: NRSA and MoRD. 2000)

Table 3: NRSA Wasteland classes (1986-2000)

\begin{tabular}{|c|c|c|c|}
\hline Wasteland map (1986-2000) & Area (M ha) & Soil degradation map (1986-1995) & Area (M ha) \\
\hline Gullied and ravinous land & 2.06 & Terrain deformation (includes agricultural land) & 10.37 \\
\hline Land affected by salinity/alkalinity & 2.04 & Salinization (including slight salinity category) & 5.89 \\
\hline Water logging & 1.66 & Water-logging (including sub-surface water-logging) & 14.29 \\
\hline Snow-covered glacial area & 5.58 & Water-logging) Ice caps & 4.10 \\
\hline Total & 11.34 & Total & 34.65 \\
\hline
\end{tabular}

[Source: NRSA and NBSS\&LUP]

Table 4: Common categories of wasteland map (NRSA) and soil degradation map (NBSS \& LUP, 2004)

\begin{tabular}{|c|c|c|c|}
\hline S. No. & Land Classes & Codes & Area (in M ha) \\
\hline \multirow{3}{*}{1} & Water Erosion & $\mathrm{W}$ & \\
\hline & Loss of top-soil & $\mathrm{Wt}$ & 83.31 \\
\hline & Terrain deformation & Wd & 10.37 \\
\hline \multirow{6}{*}{2} & Wind Erosion & $\mathrm{E}$ & \\
\hline & Loss of top-soil & $\mathrm{Wt}$ & 4.35 \\
\hline & Loss of top-soil/terrain & $\mathrm{Et} / \mathrm{Ed}$ & 3.24 \\
\hline & deformation & $\mathrm{Ed} / \mathrm{Eo}$ & 1.89 \\
\hline & Terrain & $\mathrm{C}$ & \\
\hline & deformation/over-blowing & Cs & 5.89 \\
\hline \multirow{2}{*}{3} & Chemical Deterioration & En & 16.03 \\
\hline & Salinization & $\mathrm{P}$ & \\
\hline 4 & Loss of nutrients (En) -(Acid soils) & $\mathrm{Pw}$ & 14.29 \\
\hline \multirow{4}{*}{5} & Physical Deterioration & & \\
\hline & Water-logging & \multirow{3}{*}{$\mathrm{I} / \mathrm{R} / \mathrm{M}$} & \multirow{3}{*}{8.38} \\
\hline & Others; Ice caps/ Rock & & \\
\hline & outcrops/rid mountain & & \\
\hline 6 & Total & & 147.75 \\
\hline
\end{tabular}

Table 5: Preliminary area statistics of degraded and wastelands of India ${ }^{[1]}$

\begin{tabular}{|c|c|c|c|}
\hline \multirow{2}{*}{ S.N. } & Degradation type & Area $^{\mathbf{2}} \mathbf{M}$ ha) & Land use \\
\hline \multirow{3}{*}{1.} & Water Erosion: Loss of top-soil & 13.25 & Mainly agricultural areas \\
\cline { 2 - 4 } & Gully formation & 8.31 & Mainly wastelands and partly agriculture \\
\cline { 2 - 4 } & Ravines & 2.06 & Mainly wastelands \\
\hline \multirow{3}{*}{2.} & Wind Erosion: Loss of top soil & 3.76 & Mainly agricultural areas \\
\cline { 2 - 4 } & Over blowing & 1.89 & Mar tly agriculture and partly wastelands \\
\hline \multirow{2}{*}{3.} & Terrain deformation & 3.24 & Partly agricultural \& partly wastelands \\
\cline { 2 - 4 } & Chemical Degradation: Salt-affected soils & 6.73 & Mainly agriculture areas and partly wastelands \\
\hline \multirow{3}{*}{4.} & Land degradation due to acidity & 16.03 & Mainly agricultural areas \\
\cline { 2 - 4 } & Physical Degradation: Water-logging, Surface ponding & 1.66 & Mainly wastelands \\
\cline { 2 - 4 } & Subsurface water-logging & 4.75 & Wastelands \\
\hline \multirow{3}{*}{5.} & Vegetal Degradation with Water Erosion & 40.16 & Wastelands \\
\cline { 2 - 4 } & Others: Mining and industrial waste & 0.13 & Wastelands \\
\hline
\end{tabular}

Note: 1 . Statistics encompasses degraded lands in agricultural areas and wastelands;

2. The results given in this Table are preliminary, and are based on the incomplete information. 


\section{Degraded and wastelands in the state of Madhya Pradesh, India}

Madhya Pradesh has varied topography, ranging from leveled land to hills of different elevations. Eroded land surfaces and river valleys are found between them. The Satpura, Vindhyachal and Maikal are the main mountains. The important plateaus of the state are: Malwa, Bundelkhand (Central India), Rewa-Panna (Baghelkhand), Sagar and Damoh. The state has $14.095 \mathrm{M}$ ha of degraded and wastelands which is about $45.73 \%$ of the state's geographical area. Districts with large areas of degraded lands are Khargone (7.85 Lac ha), Chhindwara (6.48 Lac ha), Dhar (6.43 Lac ha), Khandwa (5.81 Lac ha), Mandsaur (5.25 Lac ha) and Shahdol (5.08 Lac ha).

The total area affected by water erosion (including open forest areas) accounts for $13.465 \mathrm{M}$ ha (44\% of TGA). Worst affected districts are Khargone (7.79 Lac ha), Dhar (6.38 Lac ha), Chhindwara (5.88 Lac ha) and Shivpuri (4.88 Lac ha). Some districts have areas ranging from 2.00 to $4.00 \mathrm{Lac}$ ha under degraded lands. Ujjain, Balaghat, Bhind, Bhopal, Damoh, Datia, Gwalior and Tikamgarh districts have less than 2.00 Lac ha soil erosion affected areas. Soil acidity is localized, and affected districts by it are Mandla (2.16 Lac ha), Balaghat (0.83 Lac ha), Chhindwara ().58 Lac ha), Sagar (0.15 Lac ha) Vidisha (0.13 Lac ha).Sodic soils are found in Vidisha (0.28 Lac ha), Bhind (0.12 Lac ha), Morena (0.11 Lac ha), and Datia (0.04 Lac ha) [Ref: Degraded and wastelands of Madhya Pradesh Source: NBSS\&LUP].

\section{Management of soil health and crop productivity!}

Management of Land and water are interdependent on each other. Land management is not possible without water management and a vise versa. It is therefore essential that the degraded and wastelands are rehabilitated and managed in such a way so that they are rendered cultivable and may become effective in supporting food crop production, agroforestry and forestry-based land-use systems. Major considerations for effectively managing soil health and crop productivity may be;

1. Nutrient Sources.

2. Manuring.

3. Crop Rotations.

4. Intercropping.

5. Cover Crops.

6. Steep lands Systems.

7. Sewage Sludge and Bio-solids.

8. Composting.

9. Nutrient Cycling.

10. Allelopathy.

11. Tillage Systems.

12. Erosion and Pollution Control.

13. Management of Agrochemicals, etc.

Adoption of appropriate recommended practices at different levels i.e. at large scale, medium scale, community/Panchayat level and individual farmers' level following the principles of integrated watershed management would provide impetus in improving health of land resources.

\section{Watershed based development approach!}

Permanent solution for attaining water prosperity, food productivity and overall profitability lies only in integrated watershed based approach. The Definition /Meaning of WS are known to us for about Last 200 years but the advantages and Impact of WS Management Approach could attract our attention only during Second Half of $20^{\text {th }}$ Century. Last 20/30 years have witnessed a marked increase in the level of interest among R\&D organizations, administrators and policy makers, and there has been a significant increase in commitment towards this approach. The success stories of Sukhomajri and Nada (Haryana) and Ralegaon Siddhi (Maharashtra) watersheds are inspiring examples. It is through watershed approach only, we can make grey areas green, and since $68 \%$ area is still rain-fed and requires appropriate technological backstopping for sustained production so critical for the "Second Green Revolution or Ever Green Revolution".

The watershed development programme may have the specific objectives e.g.

1. To manage land and water resources of the watershed for their most optimum utilization.

2. To manage land to manage rainwater to control the problems of soil erosion, inadequate drainage, maintenance of fertility and conservation of water

3. To obtain optimum upland treatments (conservation practices) consistent with efficient land use and high income per unit area.

4. To make a substantial contribution towards flood prevention.

5. To increase productivity and income from dry lands through introduction of improved technologies with respect to components of watershed programme.

6. To conserve soil resource for achieving sustained productivity.

7. To improve collection of runoff through appropriate water harvesting systems.

8. To generate increased employment potential at village level by introducing such labor intensive technologies particularly during the 'lean' period.

9. To enhance the productivity of community lands through programme like social forestry, pasture development etc.

\section{Planning for watershed programme}

Concept of planning as understood in Industrial ventures may not be applicable in a biological system because unlike industrial project, the conditions vary from location to location and even within the same agro- ecological region. Instead of centralized planning, the watershed has to be planned from below so as to consider the needs and capability of the participants.

\section{People's participation}

People's participation and collective action are critical ingredients for watershed management. In real terms peoples' participation means voluntary sharing by the users group their time, energy and money on the programme and adopt the recommended measures and practices on a sustained basis. Sustainability, equity and participation are the three basic elements of participatory watershed management. Sustainability involves conservation and enhancement of the primary productivity of the ecosystem, the main components of which are land, water and biomass. Equity has to be seen in terms of creating an equitable access to livelihood resources for the watershed community. Participatory watershed management attempts at ensuring sustainability of the ecological, economic and social exchanges taking place in the watershed territory. This includes natural resource exchange, which is the conventional watershed management, and participatory watershed management additionally considers the economic, political and cultural exchanges. Participation of peoples of each section of the society and collective efforts 
for management of resources and their utilization on equity basis are essential ingredients for watershed management for realizing benefits on long term basis.

\section{Preparation of master plan}

The preparation of master plan is a pre-requisite and is useful document encompassing not only the site characteristics, but also socio- economic situations, existing cropping schemes and land uses, available technologies ready for transfer; infrastructures available and even the mode of monitoring the progress and inter agency coordination. A perfect master plan must have the following information:

1. General description of watershed physiography.

2. Analysis of problems and needs.

3. Resource evaluation.

4. Proven technology adoption.

5. Proposed soil and water conservation measures.

6. Proposed land use and cultural practices.

7. The animal husbandry programme should appropriately be included.

8. Cost benefit analysis.

9. Coordination and monitoring.

10. Evaluation.

Inspiring examples of ws based development approach in India:

Sincere efforts are required to have;

1. A Good National Land Use Policy.

2. A Good and effective national water use policy.

3. Urgent need for river's grid system, the state of Madhya Pradesh has taken lead by linking Narmada and Kshipra Rivers on February 6, 2014.

The recent examples of WS based approach of natural resources management seeking peoples' participation in India are;

1. Jamburdi-Hapsi, Rinjalai-Nainod WS (M.P., 1974-75) by Dr. G. P. Verma \& Team.

2. Ralegaon -Siddhi WS (M.S., 1975): by Shri Anna Hazare.

3. Sukhomanjari WS (Haryana, 1977) by Dr P. R. Mishra \&Team.

4. Tarun Bharat Sangh (Rajsthan, 1985) by Sh. Rajendra Singh.

5. Adarsh Watershed, Kothapalli (ICRISAT, A.P., 1999) by Dr. S. P. Wani \& Team.

6. Hingonia-Piplyatapha, Ringnodia, Jaitpura, GawaliPalasiya WS (M.P.) by Dr R. A. Sharma (author of this paper) and Team.

1. Ralegaon Siddhi in Maharashtra [Sh. Anna Hazare]: A village in Parner Taluka of Ahmednagar district, Maharashtra state has an area of 982.31 ha (1991). It is considered a model of environmental conservation. The village has carried out programs like tree planting, terracing to reduce soil erosion and digging canals to retain rainwater. For energy, the village uses solar power, biogas (some generated from the community toilets) and a windmill. The project is heralded as a sustainable model of a village republic. The village's biggest accomplishment is in its use of non-conventional energy. For example, all the village street lights each have separate solar panels. The village is headed by a Sarpanch who is the chief of the Gram Panchayat (village Panchayat).
In 1975 the village was afflicted by drought, poverty prevailed, and trade in illicit liquor was widespread. The village tank could not hold water as the embankment dam wall leaked. Work began with the percolation tank construction. Mr. Hazare encouraged the villagers to donate their labor to repair the embankment. Once this was fixed, the seven wells below filled with water in the summer for the first time in memory. Now the village has water year round, as well as a grain bank, a milk bank, and a school. There is no longer any poverty. The World Bank Group has concluded that the village of Ralegan Siddhi was transformed from a highly degraded village ecosystem in a semi-arid region of extreme poverty to one of the richest in the country.

\section{Sukhomajri WS in Haryana [P. R. Mishra \& Team]}

Sukhomajri is a village in the erosion prone Shivalik hills near Chandigarh in north Indian state of Haryana where there was a severe problem of erosion in the upstream catchment area leading to silting up of the downstream Sukhna Lake. In 1977, under the guidance of Dr. Mishra four tanks were built to conserve rainwater. This increased water storage and provided protective irrigation to the rain-fed crops, increasing yields. This became an incentive to the villagers to stop grazing and initiate afforestation and watershed protection in the catchment, to reduce erosion and prevent sedimentation of their tanks. As many of the grazers did not own land and thus would not benefit directly from the water and increased yields, an innovative step was taken-of splitting water ownership from land ownership. The water stored was made the property of all villagers-equally shared by both land holders and landless, thus the landed bought water beyond their share from the landless folks. The project gave increased yields in agriculture, protected forest cover, and reduced erosion. The dam and catchment management was undertaken by Hill Resource Management Societies (HRMS).

3. Tarun Bharat Sangh [Sh. Rajendra Singh]: Rajendra Singh is a well known water conservationist from Alwar district, Rajasthan in India. Also known as "Waterman of India", he won the Ramon Magsaysay Award for community leadership in 2001 for his pioneering work in community-based efforts in water harvesting and water management. He runs an NGO called "Tarun Bharat Sangh" (TBS), which was founded in 1975. Since 1985 Rajendra Singh has directed Tarun Bharat Sangh, a NGO which promotes access to water. The organization has been recognized for its success in revitalizing rivers, renewing groundwater supplies, and granting access to clean water to people who formerly had no access.

The NGO based in village Kishori-Bhikampura in Thanagazi tehsil, near Sariska Tiger Reserve, has been instrumental in fighting the slow bureaucracy, mining lobby and has helped villagers take charge of water management in their semi-arid area as it lies close to Thar Desert, through the use of johad, rainwater storage tanks, check dams and other time-tested as well as path-breaking techniques. Starting from a single village in 1985, over the years TBS helped build over 8,600 Johads and other water conservation structures to collect rainwater for the dry seasons, has brought water back to over 1,000 villages and revived five rivers in Rajasthan, Arvari, Ruparel, Sarsa, Bhagani and Jahajwali.

Alwar district was at the time largely dry and barren, At this point Rajendra Singh met a village elder, Mangu Lal Patel, who argued "water was a bigger issue to address in rural 
Rajasthan than education". He encouraged him to work on a johad, earthen check dams, which have been traditionally used to store rainwater and recharge groundwater. Eventually with the help of a few local youths he started de-silting the Gopalpura johad. When the monsoon arrived that year, the johad filled up and soon wells which had been dry for years had water. Villagers pitched in and in the next three years, it made it 15 feet deep. These facilitated a rise in the groundwater levels and helped turn the area into a "white zone". So much so that the forest department invited the NGO to take an active part in the park's management.

In 1986, people of Bhanota-Kolyala village with through Shramdaan (voluntary labour) and with the help of TBS volunteers, constructed a johad at the source of a dried Arvari River, following this villages that lay in its catchment area, and along it also built tiny earthen dams, with largest being a 244-meter-long and 7-meter-high concrete dam in the Aravalli hills; eventually when the number of dams reached 375 , the river started to flow again in 1990, after remaining dry for over 60 years. Gradually TBS built 115 earthen and concrete structures within the sanctuary and 600 other structures in the buffer and peripheral zones. The efforts soon paid off; by 1995 Aravri became a perennial river. The river was awarded the 'International River Prize', and in March 2000 ,

In the coming years, rivers like Ruparel, Sarsa, Bhagani and Jahajwali were also revived after remaining dry for decades. Abandoned villages in the areas got populated and farming activities could be resumed once again, in hundreds of drought-prone villages in neighboring districts of Jaipur, Dausa, Sawai Madhopur, Bharatpur and Karauli, where work of TBS gradually spread. By 2001, TBS had spread over an area of $6,500 \mathrm{~km} 2$, including also parts of Madhya Pradesh, Gujarat and Andhra Pradesh. It had built 4,500 earthen check dams, or johads, to collect rainwater in 850 villages in 11 districts of Rajasthan. He has also been organizing Pani Pachayat or Water Parliament in distant villages in Rajasthan to make people aware of the traditional water conservation wisdom, the urgency of groundwater recharge for maintaining underground aquifers and advocating community control over natural resources. Rajendra Singh is recipient of

1. Magsaysay Award for Community Leadership in the year 2001.

2. Jamnalal Bajaj Award in 2005 for his notable contributions.

\section{Kothapally watershed, undivided A. P. [Dr S. P. Wani} and Team]

ICRISAT started its work in the Adarsha watershed in Kothapally village, Ranga Reddy district in earlier undivided Andhra Pradesh, India in 1999. The initial phase consisted of

1. A detailed and systematic baseline characterization of the natural resource base and the socio-economic condition of the local population.

2. The formation of a consortium including local and national research institutions as well as government authorities to provide technical support.

In close collaboration with the community, ICRISAT accordingly tested, evaluated and further developed a wide range of management styles and agricultural innovations to improve the living conditions of the people in Kothapally, and to prove that scientific backstopping, participation of the rural population and the collaboration of various institutions in multi-disciplinary consortia can make a difference. Today, the community manages the watershed independently; the project has proven to be sustainable. The watershed continues to serve as a learning site for all stakeholders in water and land management throughout India and beyond. The following components are some of the technologies and management styles that ICRISAT and partners introduced in the watershed. The watershed project resulted in impacts on the livelihoods of the community and on the natural resource base. Average maize equivalent grain yield, cost of cultivation, total income, net profit and cost benefit ratio for different cropping systems at Adarsha Watershed, Kothapally, during 1999-2006.

i) Community-based organizations were strengthened and led to greater social capital for the rural population.

ii) Incomes and employment opportunities were increased. Outbound labor migration was decreased subsequently.

iii) Water availability was significantly increased (2-4 m).

iv) Soil run-off was decreased as well as the use of pesticides. v) Increased greenery and C-sequestration.

5. Jamburdi-Hapsi, Hingonia-Piplyatapha, Ringnodia and Gauli-Palasiya Watersheds in M. P. [Dr. G. P. Verma, Dr. R. A. Sharma (author of this paper) and Team]: Watershed approach based works were started in 1970s in the state of Madhya Pradesh seeking peoples' participation. A summary of on-station and on-farm watershed works have been summarized here. The scientific land use planning in such a way that maximum productivity and profits are realized by the farming community and other beneficiaries on one hand and the natural resource, LAND is also maintained in good a health. Suitable soil and water conservation practices and cropping systems according to soil category of Malwa and Nimar region conditions have been detailed in a Case Studies summarized in this paper.

\section{Land/Water management practices}

The first and foremost step before taking up any conservation measure and land use is characterization of land capability/land capacity and then employment of any suitable measure as per plan for land use.

Capability based land use: The land use appropriate to the land capability class should be identified and various operations viz., sowing, fertilizer management, cropping pattern and plant protection measures etc. Basic information regarding types of measures and land uses required for different land slope conditions is presented in Table 6.

Table 6: Soil and water conservation practices (SWCP) under different land categories.

\begin{tabular}{|c|c|c|c|}
\hline Land slope \% & Type of land. & SWCP & Example. \\
\hline 0 to 2 & Arable land, no crop limitation & Cultural practices & $\begin{array}{c}\text { Furrow-bed system, mulching intercropping, contour strip } \\
\text { cropping. }\end{array}$ \\
\hline 2 to 3-12 & $\begin{array}{c}\text { Arable land, some limitation on crops, if } \\
\text { mechanized }\end{array}$ & Major & $\begin{array}{c}\text { Contour bunding on slopes less than 6\% and rainfall less than 500 } \\
\text { mm. }\end{array}$ \\
\hline 12 to 20-25 & Mostly suitable for pasture, reforestation. & SWCP & Graded bunding, grass water- ways drops structures. \\
\hline Greater than 20-25 & Pasture, woodlots. ravines, gullies & Major SWCP & Bench terracing on permanent grass or forest land, graded ditching. \\
\hline
\end{tabular}


Cost effective conservation measures for high rainfall areas (1200 $\mathrm{mm}$ or more annual precipitation) include raisedsunken bed system, broad bed and furrows and broad bed and tied furrows. They have shown promise in conserving rain water, nutrient and soil resources and making their efficient utilization by arable crops (Gupta and Sharma, 1994). For relatively low but dependable rainfall situations (700-1000 $\mathrm{mm}$ annual rainfall), land management practices like land shaping, construction of low cost earthen mechanical structures, water diversion bunds, small cross section graded bunds, graded furrows (Gupta and Sharma, 1990, Sharma and Ranade, 2004), grassing of waterways, stabilization of gullies, reclamation of washes, and drop structures have been found effective in long run over traditional system of contour bunding or field bunding in black soil regions. Vegetative barriers alone or in combination with earthen graded bunds have been found useful and effective means of conserving land and water resources. Agronomical practices for efficient utilization of these resources have also proved beneficial on large scale. These include planting of crops on different land configurations, integrated nutrient supply system, conjunctive use of organics and chemical fertilizers, conservation of soil profile stored moisture through the use of mulches and increasing water use efficiency of crops

Land and water management practices would depend upon whether the erosion or water logging/ water stagnation or both are the problems. Practices of controlling soil erosion aim at slowing down the velocity of runoff water, allowing most of it to soak into the soil or to drain off slowly to the natural streams. Various activities are.

1. Stabilization of slopes $>6 \%$ with shallow soil by vegetative cover.

2. Bench terracing on land with slope $>6 \%$ and with deep soil.

3. Water diversion bunds.

4. Grassed waterways.

5. Mechanical structures for stabilization of waterways.

6. Graded bunds/planting appropriate vegetation on a grade.

7. Waste-weirs.

8. Gully reclamation works.

9. Water harvesting works.

Practices that control water logging and water stagnation are; water diversion bunds, grassed waterways, graded drainage channels, and stabilization works for waterways and drainage channels. The basic principle is to use land according to its capability, taking into consideration the type of land, its slope, and the depth of soil. Also, to achieve maximum moisture use efficiency; the land is to be cropped during the period in which most of the rain received. Various activities are.

1. A forestation of bare hillocks.

2. Planting grass on sloppy lands with shallow soil.

3. Short duration crops/varieties on moderately or less sloppy land with shallow soil.

4. Intercropping on medium deep soil.

5. Sequential cropping on deep soil after providing crop drainage in rainy season.

6. Growing more remunerative crops/varieties.

Some low cost conservation practices which have been found useful are;

1) Sowing crop against the slope on sloppy land.

2) Planting on grade rather than on graded broad ridges.
3) Providing surface drains/graded furrows on flat land (between crop rows).

2. Improved Package of Practices: Benefits of the conservation technologies cannot realized unless crops are grown with improved package of practices for different crops and cropping systems. These include.

1. Appropriate land management and seedbed preparation.

2. Selection of crop/varieties.

3. Seed grading/treatment.

4. Early but safe planting.

5. Judicious use of fertilizers.

6. Control of weeds.

7. Control of pests and diseases.

8. Harvest at physiological maturity.

9. Post-harvest technology and value addition etc.

3. Indigenous Rural Technologies: Traditional wisdom on 'Indigenous Rural Technologies' must also be linked and tried in a big way with suitable modifications, if any. This will not only help in maximizing agricultural production per unit of area but also trigger the people's participation in the process. There is a lot of indigenous technological knowledge (ITK) which are still being practiced in rural areas for the conservation of natural resources particularly rain water, soil and efficiently utilizing them for enhancing the productivity of crops. Some of these ITK may require refinement for realizing good results on long term basis. Some of these have which still prevail in the stae are.

1. Bunding/Bandhan Making/Pal makin.

2. Deep ploughing in summer.

3. Crop stubbles/Residue Management

4. Application of tank silt.

5. Inter-culture operation.

6. Strip Cropping.

7. Inter row Cropping.

8. Green capping.

9. Green manuring.

10. Talab/Pond.

11. Earthen bunds supported by vegetation.

12. Dug Wells.

13. Haveli/Bharel system.

14. Bandh system of cultivation.

15. Tank (Talab).

16. Earthen check dams.

\section{Small scale water conservation measures}

There are certain cost effective and simple measures which take care of in-situ water conservation as well as safe disposal of excess water.

These are ridge and furrow system, graded furrows, raised and sunken beds system, broad bed and furrows, broad bed and tied furrows, etc. as described in the following paragraphs.

i) Ridge and Furrows: Ridge and furrow system envisages planting of upland rainy season crops on ridges laid out on such soils having slope less than $1 \%$. Furrows serve an effective means of surface drainage and carry excess water into cut off drains dug across the slope. Spacing of cropped rows and rainfall would be deciding factors for specification of ridges. The system has proved highly effective in medium to high rainfall areas (rainfall ranging from 700 to $1200 \mathrm{~mm}$ ). 
ii) (Graded Furrows: In areas receiving moderate rainfall (less than $1000 \mathrm{~mm}$ ), productivity of upland rainy season crops can be substantially increased simply by providing graded furrows of 0.2 to $0.3 \%$ slope which can conveniently carry runoff water to drainage channel. Spacing between such furrows may vary from 8 to $10 \mathrm{~m}$ depending upon slope and rainfall characteristics.

iii) Broad Bed and Furrows (BBF): This system consists of a series of broad beds and furrows (Kanwar et al, 1982) accommodated in $90-150 \mathrm{~cm}$ wide parallel running strips developed with the help of two furrow openers and a bed former attached to a bullock drawn or tractor drawn tropiculture (Sharma and Gupta, 1990-96). Beds and furrows are created on a grade of $0.5 \%$. Furrows drain into grassed waterways. This system permits collection of runoff water in a tank provided down the slope. The system permits safe disposal of runoff, tends to conserve soil and water in-situ, reduces soil and nutrient losses and enhances crop productivity and sustainability (Tables 7 and 8).

Table 7: Runoff, soil loss, water use and water use efficiency of Soybean due to different land treatments (Mean of 1988-1997). [BBF=Broad bed and furrow, BBTF=Broad bed and tied furrows, RSB=Raised-sunken beds]

\begin{tabular}{|c|c|c|c|c|c|c|c|}
\hline Treatments & $\begin{array}{c}\text { Rainfall } \\
(\mathbf{m m})\end{array}$ & $\begin{array}{c}\text { Runoff } \\
(\mathbf{m m})\end{array}$ & $\begin{array}{c}\text { Soil loss } \\
(\mathbf{k g} / \mathbf{h a})\end{array}$ & $\begin{array}{c}\text { Yield } \\
(\mathbf{k g} / \mathbf{h a})\end{array}$ & $\begin{array}{c}\text { Deep Percolation } \\
(\mathbf{m m})\end{array}$ & $\begin{array}{c}\text { W.U. by Soybean } \\
(\mathbf{m m})\end{array}$ & $\begin{array}{c}\text { W.U.E. of } \\
(\mathbf{k g} / \mathbf{h a . m m})\end{array}$ \\
\hline FLAT & 831 & 111 & $\begin{array}{c}1597 \\
(\text { Tr.-4674) }\end{array}$ & $\begin{array}{c}1218 \\
(262-1790)\end{array}$ & 190 & 572 & 3.05 \\
\hline BBF & 831 & 96 & $\begin{array}{c}1117 \\
(\text { Tr.-2983) }\end{array}$ & $\begin{array}{c}1469 \\
(929-2095)\end{array}$ & 148 & 595 & 3.29 \\
\hline BBTF & 852 & 116 & $\begin{array}{c}954 \\
(\text { Tr.-2902) }\end{array}$ & $\begin{array}{c}1435 \\
(952-2100)\end{array}$ & 161 & 650 & 3.07 \\
\hline RSB & 831 & 66 & $\begin{array}{c}471 \\
(\text { Tr.-1414) }\end{array}$ & $\begin{array}{c}1433 \\
(852-2014)\end{array}$ & 252 & 571 & 3.46 \\
\hline
\end{tabular}

\section{iv) Broad bed and tied furrows (BBTF)}

This system is similar to BBF except that furrows are tied with small cross section earthen bunds at a regular interval of $10 \mathrm{~m}$ in mid August month to retain runoff, if any, towards the end of rainy season for the benefit of rainy season crops during reproductive growth phase. In a long term study conducted by authors (Tables 7) average reduction in the loss of soil due to sheet erosion, N, P, K and S was $40.3 \%, 3.5 \%$, $13.5 \%, 16.9 \%$, and $1.1 \%$ respectively while enhancement in soybean seed yield, water use by crop and water use efficiency was $17.8 \%, 13.6 \%$ and $0.7 \%$ respectively due to broad bed and tied furrows system over conventional system.

v) Raised and sunken bed system (RSB): During rainy season in black soil regions, crops often suffer due to poor drainage during periods of continuous and intense rainfall. On sloppy lands, runoff causes severe soil and nutrient losses. RSB system takes care of these problems as it is of semi-permanent nature and consists of an array of raised and sunken beds of 6-8 $\mathrm{m}$ and $3-4 \mathrm{~m}$ widths respectively, with elevation difference of $15-30 \mathrm{~cm}$. The system is created by mechanically shifting soil from demarcated 3$4 \mathrm{~m}$ wide strips, designated as sunken beds to adjoining 6$8 \mathrm{~m}$ wide strips called raised beds. Sunken beds are tied with small cross section earthen bunds of about $10 \mathrm{~cm}$ height at $20 \mathrm{~m}$ distance interval to ensure uniformity in runoff retention. Raised and sunken bed system ensures surface drainage, encourages in-situ rain water conservation and retards soil erosion and nutrient losses to a considerable extent. The runoff from raised beds, planted to any upland crop, is arrested in the adjacent sunken beds supporting a relatively water tolerant crop such as upland rice. The dimensions of beds would depend on many factors viz; rainfall amount and intensity, runoff potential and water intake rate of soil under consideration. For example, in central parts of the state of Madhya Pradesh, India, water intake rate of soil is poor (4-6 $\mathrm{mm} /$ hour $)$ and annual rainfall is high ( $>1200 \mathrm{~mm}), 3$ to $6 \mathrm{~m}$ wide raised beds with elevation difference of 20 to $30 \mathrm{~cm}$ have been observed to work successfully (Gupta et al, 1978) while for western regions of the state, where water intake rate of soil is relatively high ( $10-12 \mathrm{~mm} /$ hour $)$ and rainfall is moderate ( less than $1000 \mathrm{~mm}$ ), $8 \mathrm{~m}$ wide raised beds alternated by $4 \mathrm{~m}$ wide sunken beds with elevation difference of 15 to $20 \mathrm{~cm}$ have been found suitable (Gupta and Sharma, 1990a, Gupta and Sharma, 1990b, Sharma and Gupta, 1990, Gupta and Sharma, 1994) for conserving rain water, soil and plant nutrients insitu and significantly high soybean yields particularly in heavy rainfall seasons.

Table 8: Yield of soybean, loss of soil and plant nutrients due to different land Treatments (Mean of 1991-1997 (Tr.=traces, Values in parentheses are range during the study period).

\begin{tabular}{|c|c|c|c|c|c|c|}
\hline \multirow{2}{*}{ Treatments } & \multirow{2}{*}{$\begin{array}{c}\text { Yield } \\
\text { (kg/ha) }\end{array}$} & \multirow{2}{*}{$\begin{array}{l}\text { Soil loss } \\
\text { (kg/ha) }\end{array}$} & \multicolumn{4}{|c|}{ Nutrient loss (kg/ha) } \\
\hline & & & $\mathbf{N}$ & $\mathbf{P}$ & $\mathbf{K}$ & $\mathbf{S}$ \\
\hline FLAT & $\begin{array}{l}1218 \\
(262- \\
1790)\end{array}$ & $\begin{array}{c}1597 \\
(\text { Tr.-4674) }\end{array}$ & $\begin{array}{l}17.91 \\
\text { (Tr.- } \\
34.9 \text { ) }\end{array}$ & $\begin{array}{c}0.37 \\
\text { (Tr.- } \\
0.8 \text { ) }\end{array}$ & $\begin{array}{c}0.77 \\
\text { (Tr.- } \\
0.8 \text { ) }\end{array}$ & $\begin{array}{l}8.52 \\
\text { (Tr.- } \\
14.6)\end{array}$ \\
\hline $\begin{array}{l}\text { BBF-Broad bed \& } \\
\text { furrows }\end{array}$ & $\begin{array}{l}1469 \\
(929- \\
2095)\end{array}$ & $\begin{array}{c}1117 \\
\text { (Tr.-2983) }\end{array}$ & $\begin{array}{c}15.03 \\
\text { (Tr.- } \\
21.35)\end{array}$ & $\begin{array}{c}0.32 \\
(\mathrm{Tr} .- \\
0.75)\end{array}$ & $\begin{array}{l}0.84 \\
\text { (Tr.- } \\
1.12 \text { ) }\end{array}$ & $\begin{array}{l}9.11 \\
\text { (Tr.- } \\
13.5) \\
\end{array}$ \\
\hline $\begin{array}{l}\text { BBTF-Broad bed \& } \\
\text { tied furrows }\end{array}$ & $\begin{array}{l}1435 \\
(952- \\
2100)\end{array}$ & $\begin{array}{c}954 \\
\text { (Tr.-2902) }\end{array}$ & $\begin{array}{l}17.28 \\
\text { (Tr.- } \\
7.89)\end{array}$ & $\begin{array}{l}0.32 \\
\text { (Tr.- } \\
0.73 \text { ) }\end{array}$ & $\begin{array}{l}0.64 \\
\text { (Tr.- } \\
0.66 \text { ) }\end{array}$ & $\begin{array}{l}8.43 \\
\text { (Tr.- } \\
13.2 \text { ) }\end{array}$ \\
\hline $\begin{array}{l}\text { RSB-Raised \& } \\
\text { Sunken beds }\end{array}$ & $\begin{array}{l}1433 \\
(852- \\
2014)\end{array}$ & $\begin{array}{c}471 \\
(\text { Tr.-1414) }\end{array}$ & $\begin{array}{l}9.26 \\
\text { (Tr.- } \\
5.99)\end{array}$ & $\begin{array}{l}0.28 \\
\text { (Tr.- } \\
0.64)\end{array}$ & $\begin{array}{l}0.38 \\
\text { (Tr.- } \\
0.44 \text { ) }\end{array}$ & $\begin{array}{l}5.48 \\
\text { (Tr.- } \\
11.5 \text { ) }\end{array}$ \\
\hline
\end{tabular}

\section{Medium scale soil erosion control measures}

Erosion control measures include various mechanical, biological and agronomic practices as discussed below:

A. Mechanical measures: Some of the cost effective and promising erosion control measures are discussed below:

\section{i) Gabion structures (Loose boulders structures)}

"Gabion" structures have been successfully used on large scale in black clay soils (Verma and Raje, 1981) for reclaiming gullies. A "gabion" is a flexible structure of loose boulders packed into prefabricated galvanized iron wire netting. Drop structures of various sizes and shapes can be made by placing a number of such boxes (gabions) together at the top of one another as per requirement. Gabions have been found more effective than masonry structures of the same design as they are porous, flexible and allow the runoff water to pass through while retaining the silt upstream. Because 
they are flexible in nature, gabions are highly suited to black soils which exhibit structural changes during wetting and drying.

ii) Graded Bunds: Mechanical bunds of $0.3 \mathrm{~m}^{3}$ cross section are laid along a grade of $0.3 \%$. They have been reported to minimize soil erosion from lands up to 6\% slope (Verma, 1981). The optimum vertical interval for graded bunds for land slope up to $1.5 \%, 2 \%, 3 \%, 4 \%, 5 \%$, and $6 \%$ has been reported as $1.3 \mathrm{~m}, 1.5 \mathrm{~m}, 1.7 \mathrm{~m}, 1.8 \mathrm{~m}, 2.0 \mathrm{~m}$, and $2.2 \mathrm{~m}$ respectively (Gadkary, 1966).

iii) Conservation Ditches: In vertisols, conservation ditches can also be adopted, which serve the dual purpose of terrace and small water storage structures (Patnaik et al, 1982).

iv) Water Diversion Bunds: Diversion of runoff water coming off a hillock or upper land reaches into cropped fields saves the land from inundation, erosion and degradation. This can be achieved by constructing a bond with a shaped drainage channel along it on a grade of 0.2 to 0.3 per cent. The cross section of the bund will depend upon the rate of runoff and catchment area contributing runoff to be diverted. The base width of $1.0 \mathrm{~m}, 1.5 \mathrm{~m}, 2.3$ $\mathrm{m}$, and $3.5 \mathrm{~m}$ for 20ha, 30ha, 40ha and 50ha catchments area, respectively has been suggested by Gadkary (1966). The optimum side slope of a bund is considered to be 1.5 to 2.0: 1.0. If the catchment area includes a bare hillock, the base width has to be increased by about $50 \%$ and pitching with boulders at the bunds may also be required. Appropriately located diversion bunds lead the water safely into a natural drain or into a grassed waterway either constructed or available for this purpose.

v) Bench Terracing: Bench terracing coupled with suitable plantation of trees and grasses on lands having more than $6 \%$ slopes is an effective measure of erosion control.

vi) Grassing of Waterways: Grassed waterways are required to be constructed at suitable sites to lead water diverted by storm drains or water diversion bunds and graded bunds to natural stream. The cross section of a waterway would depend upon the rate of runoff, catchment area and of permissible velocity of flowing water. The permissible velocity of flowing water for a bare sandy soil, bare clay soil, grassed soil, and weathered basalt (Murrum) or hard rock are $0.5,1.0,1.4$ and $1.7 \mathrm{~m} /$ second, respectively (Verma, 1981). If the bed of waterway is too deep, it gets eroded when the velocity of water exceeds these limits and in such cases the bed of waterway should be stabilized by constructing suitably designed gabion structures at appropriate sites.

vii)Stabilization of Washes: Washes formed in the cultivated fields may develop into gullies if not controlled in initial stages. Stabilization of such washes can be achieved by leaving that strip of land uncultivated over which water flows so that grasses may be planted initially and some may develop naturally. If a wash is in advanced stage of erosion and getting deeper and wider every rainy season, it is essential to provide drop structures. For a shallow wash (depth up to $50 \mathrm{~cm}$ ), a rectangular weir type drop structure of loose boulders at appropriate site with reverse filter (consisting of pebbles, gravels and sand layers) upstream from the structures will be sufficient. For deeper washes (depth more than $50 \mathrm{~cm}$ ), appropriate gabion structures are necessary.

viii) Provision of Drainage between Waterways: Safe disposal of runoff water from areas between waterways is essential. For this, construction of open drainage channels on a grade at suitable intervals from ridge to grassed waterway has been found effective. The cross section of drainage channels will depend upon the rate of runoff and the area of its catchment. Depending upon the difference in the bed level of the grassed waterway and those of fields to be drained, drains or suitable fall structures have to be provided.

ix) Gully Control: Stabilization and reclamation of gullies is very essential as otherwise gullies go on widening and deepening with time due to falling of banks and bed erosion. The menace continues forever as side gullies start developing from secondary and tertiary washes resulting into the formation of a network of small shallow-narrow and big wide and deep gullies. In long run a lot of cultivable and fertile land turns into waste and unproductive lands. Construction of drop structures in the gully at appropriate points, planting or seeding of suitable grass species at the bed and on the sides of gullies help in stabilizing them. Fast growing locally available grass species may be useful for this purpose. Repeated seeding / planting of grass species in the beginning, middle and end of rainy season is essential to ensure good vegetative cover.

(B). Biological Measures: Biological measures are generally used as preventive measures. These include appropriate plant cover, straw mulching, vertical mulching with stalks of maize or sorghum or any other crop residues and vegetative barriers.

i) Planting of a Cover Crop: A rainy season crop which tends to develop a thick canopy, intercepts rainfall and dissipates energy of falling rain drops is helpful in reducing soil erosion. Soybean, maize and sorghum crops are effective in this regard as they develop canopy at fast rate.

ii) Mulching with Crop Residues: Application of crop residues is effective in enhancing the infiltration and reducing runoff. The immediate advantage of incorporation of crop residues in soil is to enhance infiltration and retard runoff losses. Later on, upon decomposition, it adds nutrients for the benefit of crops and enhances water use efficiency. Usually they can be applied at the rate of 5 to $8 \mathrm{t} / \mathrm{ha}$. After emergence and establishment of crops, straw or crop residues may be spread in between crop rows. Straw mulching, besides reducing erosion and enhancing infiltration, increases water use efficiency of crops to a considerable extent (Sharma et al 1985a, Sharma et al 1985b).

iii) Vegetative Barriers/Hedges: Vegetative barriers/ hedges have been found useful in reducing the rain water runoff water and conserving soil and plant nutrients. These are also helpful in stabilizing the earthen bunds. For this purposes a number of grass species have been identified. Grasses such as vetiver, Cymbopogon martinii have proved to be useful. Vegetative hedges are established at 0.5 to $0.75 \mathrm{~m}$ vertical interval. Two rows planted $30 \mathrm{~cm}$ apart make a good hedge which should be regularly cut to maintain $30 \mathrm{~cm}$ height.

(C). Agronomic Measures: Agronomic practices which encourage conservation of soil, rain water and plant nutrients and enhance use efficiency of these resources are soil mulching, plastic mulching, contour farming, strip cropping, integrated nutrient management practices and minimum tillage practices etc. 
i) Soil Mulching/Shallow Inter-culture/ Shallow Tillage: Soil mulch created in-situ is known to reduce evaporation by minimizing and delaying formation of shrinkage cracks besides providing a diffusion barrier (Sharma and Gupta, 1984, Gupta and Sharma, 1990b, and Sharma and Gupta, 1990). Soil mulching may be created by operating the suitable implement (hand-hoe, blade harrow etc.) in between crop rows as and when required. Effectiveness of soil mulching varies with the crop type. On an average 6 to 25 per cent increase in water use efficiency of post rainy season crops can be realized due to soil mulching.

ii) Deep Tillage Practices: Deep tillage prior to onset of rainy season is practiced mainly with a view to increase infiltration and thereby reduce runoff, soil erosion and weed population. Off season deep tillage, particularly in subnormal rainfall years, has been found useful in conserving the soil and water resources and enhancing the crop yields substantially.

iii) Plastic Mulching: Plastic mulches although conserve soil profile stored moisture leading to sustainable increase in water use efficiency and crop yields but they are not cost effective for large scale adoption (Sharma, 1976). They can be of immense use for soil solarization (meant for minimizing the incidence of weeds and soil borne diseases), or for growing cash crops.

iv) Contour Farming: Any tillage operations done along the contour lines create numerous ridges and furrows which retain a good volume of rain water after each wet spell. This water eventually infiltrates into soil. There is corresponding reduction in runoff volumes and therefore in erosion of soil and plant nutrients. Experiments conducted long back at Ootacamund (India) have shown that by adopting contour farming for potato, cultivated on $25 \%$ slope, runoff was reduced from 52 to $29 \mathrm{~mm}$ and soil loss from 39 to $15 \mathrm{t} / \mathrm{ha}$ when rainfall received was moderate.

v) Strip Cropping: Strips of suitable cover crops grown in the same field along contours control water erosion. Broad leaf pulses and grasses usually provide effective strips for reducing runoff and erosion.

vi) Runoff Farming: Harvesting of runoff at micro level, its storage and recycling for life saving irrigation during long dry spells improve productivity of a rainy season crop. The water thus stored can also be used for establishment of a post rainy season crop. This practice if adopted on large scale is potentially capable of addressing twin problems of water stagnation during Kharif and moisture stress during Rabi. An appropriate land management system combined with water harvest and recycling system seem to offer vast prospects of improving productivity of Indian vertisols even under rain-fed conditions.

vii)Minimum Tillage: Minimum possible disturbance of soil surface can save soil from erosion to some extent. For erosion control in gently sloping areas, mixed cropping or intercropping may be practiced in order to cover the maximum surface for a longer period. Minimum tillage during post rainy period reduces evaporation from soil, improves establishment of post rainy season crop (Sharma, 1990a). viii) Integrated Nutrient Management: Integrated fertility management envisages the conjunctive use of organics such as FYM, compost, green manures, crop residues, and bio-fertilizers. Long term studies conducted on black soils of high rainfall region (Sharma, 1990b, Sharma, 1992, Sharma and Gupta, 1993) amply reveal that conjunctive use of FYM and chemical fertilizers lead to;

(a) Improvement in organic pool of soil and nutrient status of soil.

(b) Mitigation of drought effect on crop.

(c) Enhanced sustainable yield index.

(d) Significantly higher biomass production per unit land than that obtained through use of chemicals alone.

ix) Capability Based Land Use: Land use must be planned based on its capability classes as any abuse of land at any point of time would be the beginning of land deterioration at a very faster rate. For example, shallow black soils must be planted to kharif crops for providing vegetative cover during rainy season as well as for harvest good crops, while Intercropping and double cropping may be practiced on medium depth and deep soils for obvious reasons. Planning for crops and cropping system must be matched with water availability period of the soils.

(D). Alternate Land Use Systems: A number of options of alternate land use systems have been identified for different locations (Singh, 1988). Different high value crops like medicinal plants, spices, trees, etc. Pastures and Livestock have got their own importance to find place for making alternate land uses under rain-fed situations. The biodiversity of native vegetation in dry lands has been comprehensively reviewed by Suresh Kumar (1999). Trees, shrubs and native pastures are the most important natural vegetation sources. Several multipurpose tree species yielding timber, fodder and fuel wood grow in SAT region on field bunds and scattered in the fields (park land system). This is a traditional agroforestry system. Recent research has focused upon systematic integration of trees, crops and grasses through agri-silviculture, horticulture and silvi-pasture. Nitrogen fixing trees (NFTs) have a special role in rain-fed farming systems from the point of view of nutrient cycling.

Agro-horticulture: In medium soil areas receiving annual rainfall of more than $750 \mathrm{~mm}$, agro- horticultural systems consisting of a fruit trees intercropped with annual arable crop is recommended. Ber, Custard apple, Aonla, drumsticks, plums, and pomegranate are some of the species suitable for dry lands, both for pure plantations and mixed with crops. Cluster bean, cowpea, horse gram, and other grain legume have been found useful in this context in the dry tracts. Results of a long term experiment conducted at AICRPDA, Indore, as an example of the advantages of agro-horti system have been presented in Table 9 (Sharma and Sharma, 2019). Results revealed tremendous scope of alternate land use of combining fruit trees and prevalent crops of Soybean, Pigeonpea and their intercrop combination.

Table 9: Agro-horti System, AICRPDA, Indore (1999 to 2003).

\begin{tabular}{|c|c|c|c|c|c|}
\hline Treatments & $\begin{array}{c}\text { Mean Yield of arable } \\
\text { crops (kg/ha) }\end{array}$ & $\begin{array}{c}\text { Yield Range of arable } \\
\text { crops (kg/ha) }\end{array}$ & $\begin{array}{c}\text { Mean gross return } \\
\text { (Rs./ha) }\end{array}$ & $\begin{array}{c}\text { Soybean Equivalent Yield } \\
\text { (kg/ha) }\end{array}$ & $\begin{array}{c}\text { Yield range } \\
\text { (kg/ha) }\end{array}$ \\
\hline Aonla-Sole soybean & 1290 & $940-2177$ & 13372 & 1539 & $1054-2321$ \\
\hline Aonla-Sole pigeon-pea & 1130 & $384-1765$ & 18728 & 2255 & $534-4069$ \\
\hline
\end{tabular}




\begin{tabular}{|c|c|c|c|c|c|}
\hline Drumstick-Sole soybean & 1243 & $955-1973$ & 13098 & 1488 & $1084-2109$ \\
\hline Drumstick-Sole pigeon-pea & 1195 & $472-2025$ & 19859 & 2388 & $639-4656$ \\
\hline Ber-Sole Soybean & 1119 & $838-1837$ & 11599 & 1332 & $933-1962$ \\
\hline Ber-Sole pigeon-pea & 1118 & $378-1834$ & 18579 & 2214 & $665-4255$ \\
\hline
\end{tabular}

Case studies of integrated Ws development work in M. P. The major practices executed for development of watershed through ICAR funded Operational Research Projects at COA, Indore consisted of;

1. Planting of improved grasses and leguminous forage mixed with grasses on sloppy land (slope $>6 \%$ ) in upper reaches of the watershed starting from the ridge which was under the scrub forest, trees for fuel and fodder (e.g. Subabool).

2. Construction of a "water diversion bunds" between the land under scrub forest and the cultivated land below to divert the excessive runoff from the bare hillocks/ scrub forest away from the cultivated land.

3. Stabilization of the main gully of the micro watershed through loose boulder structures with reverse filters where the depth of gully was $50 \mathrm{~cm}$ or less. Where the depth of gully was more than $50 \mathrm{~cm}$, a proper size of "Gabion structure" with reverse filter was made. Such structures have proved very successful for gully control on black soils.

4. Stabilization of main gullies, the whole cultivated land on both sides of the main gully was divided into small segments by planting vegetation (e.g. vetiver or munj or Saccharum sp.) or construction of graded bunds across the slope.

5. Depending upon the specific site, the runoff collection structures were constructed. At some places submersible check dams were constructed to hold rain water which could be recycled, while at other places at suitable sites tanks were constructed. In the beginning, such tanks served the purpose of percolation tanks and later on (after 2-3 years); these tanks hold water due to clogging of the pores with silt particles. Also, rejuvenation of old tanks existing in watershed was also necessary and various activities were undertaken. Farmers preferred to dig their own wells rather than farm ponds.
6. Introduction of crops/ varieties according to the moisture availability period which is governed by land slope, depth of soil, texture of soil and distribution of rainfall. Some other activities undertaken were livestock improvement, improved fodder cultivation, animal health related activities, etc. In the state of M. P. agriculture research and development studies were initiated in a big way in the year 1974 first in the leadership of Dr. G. P. Verma. Later on the work was carried forward by different scientists. The results of which are still relevant and clearly indicate the positive effects of natural resource conservation measures on productivity enhancement and over all prosperity of the area. A summary of the few case studies have been given as below:

Case study 1: Location and Period: Jamburdi-Hapsi, Rinjlai and Nainod. Watershed (Indo- UK Project), Indore (1974-75 and 1985-86):

General features of the project area: The project area covers three villages Jamburdi-Hapsi, Rinjlai and Nainod. The project area is about 2301 hectares out of a total of 2712 hectares occupied by the three villages. In these watersheds interventions related to soil and water conservation, stabilization of gullies, water storage and its recycling, introduction of high yielding varieties of arable crops, fodder, fruit plants, improved cattle breed, improved package of practices for all the crops were made. Activities for upgrading the skills of farmers were undertaken by organizing meetings, farmers' fairs, farmers' training etc. All these activities helped in rejuvenating the natural resources, overall improvement in productivity of crops and live-stocks and thereby improving socio-economic status of the farming community as indicated from the data presented in the following paragraphs Tables 10 through 17 .

\section{Important crops (area and productivity)}

Table 10: Status of cultivation in base and assessment years (1974-75 and 1985-86).

\begin{tabular}{|c|c|c|c|c|c|}
\hline Crop(s) & Area (ha) & Yield (q/ha) & Crop(s) & Area (ha) & Yield (q/ha) \\
\hline Sorghum local & $189-44.0^{*}$ & $4.80-8.35^{* *}$ & Sorghum improved & $161-87.9^{*}$ & $6.80-23.05^{* *}$ \\
\hline Soybean local & NA-22.0* & $4.28-6.50^{* *}$ & Soybean improved & $132-979^{*}$ & $5.60-9.75^{* *}$ \\
\hline Wheat, dry local & $582-264^{*}$ & $5.00-9.04^{* *}$ & Wheat dry improved & - & $6.39-12.80^{* *}$ \\
\hline Wheat irrigated & $115-247^{*}$ & $16.70-31.16^{* *}$ & Gram irrigated & $10-517^{*}$ & NA-10.89** \\
\hline Gram dry local & $583-216^{*}$ & $4.38-5.40^{* *}$ & Gram dry improved & - & $5.70-8.51$ \\
\hline
\end{tabular}

Change in crop area from 1974-75 to 1986, ** Change in crop yield from 1974-75 to 1986.

2. Animal population and milk production: Increase in cattle population due to developmental works in the area has been presented in Table 11. Table 12 presents the data regarding changes in milk production before and after the inception of project. Jersey crossbreeding for local cows and Murrah cross breeding for local buffaloes had a positive impact on milk production and variety of farmbullocks.

Physical Achievements: Physical achievements include ground water recharge, developing irrigation potential, increase in cattle population and milk yield, improved cropping programmes, increased productivity of crops, crop diversification etc. All the measures of soil and water conservation helped in increasing the availability of ground water for drinking as well as for irrigation as indicated by significant increase in the number of wells and pump setts in the area (Table 12).

Table 11: Status of cattle population in the watershed area.

\begin{tabular}{|c|c|c|}
\hline \multirow{2}{*}{ Livestock } & \multicolumn{2}{|c|}{ Cattle Population in different years } \\
\cline { 2 - 3 } & $\mathbf{1 9 7 3 - 7 4}$ & $\mathbf{1 9 7 8 - 7 9}$ \\
\hline Cows & 316 & 294 \\
\hline She-buffaloes & 295 & 355 \\
\hline Bullocks & 403 & 485 \\
\hline Calves and heifers & 557 & 731 \\
\hline
\end{tabular}


Table 12: Changes in water sources and milk production in the area.

\begin{tabular}{|c|c|c|}
\hline Milk production (per animal, litres/day) & Base year (1974-75) & Assesment year (1986) \\
\hline Number of wells in WS & 120 & 284 \\
\hline Number of pump sets in WS & 13 & 254 \\
\hline Cow milk production (litre/animal. day) & 1.80 & 3.12 \\
\hline Buffaloe milk production (litre/animal. day) & 3.50 & 5.19 \\
\hline
\end{tabular}

Table 13: Consumption of nutrients in watershed (in tons)

\begin{tabular}{|c|c|c|c|c|}
\hline Year & $\mathbf{N}$ & $\mathbf{P}_{2} \mathbf{O}_{\mathbf{5}}$ & $\mathbf{K}_{\mathbf{2}} \mathbf{O}$ & Total nutrients \\
\hline 1974-75 (Base year) & 43.6 & 33.3 & 7.1 & 83.9 \\
\hline 1984-85 (Assessment year) & 760.8 & 887.3 & 186.5 & 1675.1 \\
\hline
\end{tabular}

Table 14: Increase in cropping and intensity

\begin{tabular}{|c|c|c|c|c|c|}
\hline Year & Net cropped area (ha) & Double cropped area (ha) & Total cropped area (ha) & Net irrigated area (ha) & Cropping Intensity (\%) \\
\hline $1974-75$ & 1946 & 156 & 2102 & 160 & 108 \\
\hline $1984-85$ & 1986 & 1078 & 3006 & 520 & 151.3 \\
\hline
\end{tabular}

Diversification in agriculture: Some data on the benefits of watershed development works have been presented in Tables 15 through 17 as presented below.

Table 15: Average yield of local and improved (Imp) cultivars of crops (Kg/ha)

\begin{tabular}{|c|c|c|c|c|c|c|c|c|c|c|c|c|}
\hline \multirow{2}{*}{ Year } & \multicolumn{2}{|c|}{ Sorghum } & \multicolumn{2}{c|}{ Maize } & \multicolumn{2}{c|}{ Soybean } & \multicolumn{2}{c|}{ Wheat dry } & \multicolumn{2}{c|}{ Wheat irrigated } & \multicolumn{2}{c|}{ Gram dry } \\
\cline { 2 - 14 } & Local & Imp. & Local & Imp. & Local & Imp. & Local & Imp. & Local & Imp. & Local & Imp. \\
\hline $1975-76$ & 400 & 660 & 300 & 860 & 420 & 568 & 500 & 630 & - & 1678 & 48 & 570 \\
\hline $1984-85$ & 780 & 2157 & - & 1385 & 580 & 765 & 645 & 850 & - & 2470 & 405 & 520 \\
\hline
\end{tabular}

Table 16: Change in human and bullock labour employment in the project area

\begin{tabular}{|c|c|c|c|c|c|}
\hline \multirow{2}{*}{ Year } & \multirow{2}{*}{$\begin{array}{c}\text { Total cropped } \\
\text { area (ha) }\end{array}$} & \multicolumn{2}{|c|}{ Human labour days } & \multicolumn{2}{c|}{ Bullock pair days } \\
\cline { 3 - 6 } & & Per ha & Total (thousands) & Per ha & Total (thousands) \\
\hline $1974-75$ & 2178 & 19 & 41.38 & 5.5 & 11.98 \\
\hline $1978-79$ & 2629 & 25 & 65.73 & 7.0 & 18.40 \\
\hline
\end{tabular}

Table 17: Change in area and production of important crops.

\begin{tabular}{|c|c|c|c|c|c|c|c|c|}
\hline \multirow{2}{*}{ Crop } & \multicolumn{4}{|c|}{ Area (ha) } & \multicolumn{4}{c|}{ Production (q) } \\
\cline { 2 - 10 } & $\mathbf{1 9 7 5 - 7 6}$ & $\mathbf{1 9 7 8 - 7 9}$ & Difference & \% Change & $\mathbf{1 9 7 5 - 7 6}$ & $\mathbf{1 9 7 8 - 7 9}$ & Difference & \% Change \\
\hline Sorghum & 383 & 465 & 83 & +21 & 2016 & 6283 & 4267 & +212 \\
\hline Maize & 64 & 105 & 41 & +64 & 397 & 893 & +125 \\
\hline Soybean & 85 & 228 & 143 & +168 & 476 & 1968 & 1492 & +313 \\
\hline Wheat & 672 & 688 & 16 & +2 & 6290 & 8524 & 2234 & +36 \\
\hline Gram & 644 & 580 & -64 & -10 & 3272 & 3381 & +109 & +3 \\
\hline Total & 1848 & 2066 & 218 & +12 & 12451 & 21049 & 8598 & +69 \\
\hline
\end{tabular}

Case Study 2; On-farm WS research and development: Location and Period: Ringnodia Micro-Watershed (ADBICRIS A-JNKVV Project), Indore (1998-99-2005):

Various interventions included, creation of new water storage/percolation structures, de-silting of already existing ponds, water diversion bunds, loose boulder structures, gabion structures, stabilization of bunds, gully plugs, different land treatments, introduction of improved varieties of crops, crop diversification activities, integrated nutrient management practices, soil test based fertilizer application, integrated plant protection measures, cattle improvement programmes, fodder programme, vaccination of cattle, and human resource development activities by organizing various kind of trainings for skill up gradation in farming, value addition, in agricultural produce, etc. Resource conservation activities helped in erosion control and ground water recharge in the tube wells of WS, increase in the irrigated area and overall enhancement in the productivity of almost all the crops.

Progress/Development Indicators: Observations gathered through PRA done in the month of April 2005 clearly revealed the significant positive impact of different interventions as summarized in the Table 18.

Table 18: Over all progress in the Ringnodia WS due to interventions through the project.

\begin{tabular}{|c|c|c|c|c|}
\hline \multirow{2}{*}{ S. NO. } & \multirow{2}{*}{ Progress Indicators } & Base year & April, 2005 & \% Change \\
\cline { 2 - 5 } & Human population & $855(425 \mathrm{M}+420 \mathrm{~F})$ & $942(552 \mathrm{M}+390 \mathrm{~F})$ & +10.2 \\
\hline 1. & Literacy level (\%) & 40 & 48 & +20.0 \\
\hline 2. & Productivity of crops (kg/ha): & & & $+22.2-80.0$ \\
\cline { 2 - 5 } 3. & (1) Soybean & $900-1000$ & $1100-1800$ & $+26.3-42.9$ \\
\cline { 2 - 5 } & (2) Maize mix & $950-1050$ & $2400-1500$ & $+41.2-44.0$ \\
\cline { 2 - 5 } & (3) Wheat (Mexican) & $1700-2500$ & & \\
\hline
\end{tabular}




\begin{tabular}{|c|c|c|c|c|}
\hline & (4) Rain-fed chickpea & $700-800$ & $800-1000$ & $+14.3-25.0$ \\
\hline & (5) Chickpea (Partially irrigated) & 0 & $1400-1800$ & - \\
\hline & (6) Potato & $19-21(\mathrm{t} / \mathrm{ha})$ & $24-28(\mathrm{t} / \mathrm{ha})$ & $+26.3-33.3$ \\
\hline \multirow{2}{*}{4.} & Irrigated area (Fully) & $15-20 \%$ & $20-25 \%$ & $+33.3-25$ \\
\hline & Partially irrigated & $25 \%$ & $30-40 \%$ & $+20.0-16.6$ \\
\hline \multirow{6}{*}{5.} & Assets: (1) Number of tractors & 14 & 14 & 00.0 \\
\hline & (2)Number of Cultivators & 14 & 14 & 00.0 \\
\hline & (3) Number of seed drills & 7 & 14 & +100.0 \\
\hline & (4) Potato planters & 10 & 05 & -50.0 \\
\hline & (5) Sprayers & 50 & 60 & +20.0 \\
\hline & (6) Threshers & 50 (small size) & 10 (Big size) & - \\
\hline \multirow{4}{*}{6.} & Livestock population: (1) Buffaloes & & 300 & - \\
\hline & (2) Cows & & $50(20$ local +30 crossbred $)$ & - \\
\hline & (3) Oxen & & 50 & - \\
\hline & (4) Goats & & 100 & - \\
\hline \multirow[b]{2}{*}{7.} & $\begin{array}{c}\text { Water Resources: } \\
\text { (1) Number of open dug wells }\end{array}$ & 14 & 14 (all non-functional) & 00.0 \\
\hline & \begin{tabular}{|} 
(2) Number of tube wells: \\
Maximum depth of tube wells in base year \\
was $110-320$ feet,
\end{tabular} & 19 & 139 & $\begin{array}{l}\text { Out of } 139,35 \text { are } \\
\text { functional. }\end{array}$ \\
\hline \multirow[t]{3}{*}{8.} & $\begin{array}{l}\text { Fertilizer consumption: } \\
\text { (1) Nitrogen }(\mathrm{kg} / \mathrm{ha})\end{array}$ & $40-60$ & $60-120$ & +50.0 \\
\hline & (2) Phosphorus (kg/ha) & $30-60$ & $80-100$ & +100.0 \\
\hline & (3) Potash (kg/ha) & $0-53$ & $10-60$ & +13.2 \\
\hline \multirow{3}{*}{9.} & $\begin{array}{l}\text { Gross family income (Rs./Year): } \\
\text { (1) Large farmers }\end{array}$ & 200,000 & 250,000 & +25.0 \\
\hline & (2) Meadium farmers & 150,000 & $150,000-180,000$ & +20.0 \\
\hline & (3) Small farmers & 100,000 & $100,000-150,000$ & +50.0 \\
\hline
\end{tabular}

Case Study 3: On-farm research and development: Location and Period: (NATP/RNPS-2) Gauli Palasiya MicroWS, Mhow, Indore (2001-2004):

The major activities undertaken included; diversion drain, pitching and strengthening of banks of gullies and waterways, construction of water harvesting /percolation tanks and checkdams, gully control, in-field conservation activities and ground water recharge. A total of 1,32,000 $\mathrm{cu} \mathrm{m}$ of runoff water could be stored in 8 water harvesting /percolation tanks and 3 check dams and resulted in increased groundwater level of nearby tube wells and dug wells to the tune of $5 \mathrm{~m}$. The hillock runoff water diverted and stored in water harvesting tanks could protect about 100 ha of land from erosion and formation of small gullies. The loose boulder structures controlled the formation of gullies by way of reducing velocity of runoff water. Field bunding (mechanical and vegetative) could bring down the slope of cultivated fields from $2.0-3.0 \%$ to $0.5-1.0 \%$. All these resource conservation practices helped increasing the quantity of available water in the micro-watershed, which ultimately resulted in increase of cropping intensity (three crops in a year) in approximately 100 ha area. The run-off events recorded during rainy seasons of 2003 and 2004 revealed that the run-off in treated section was $9.66 \%$ and $17.25 \%$ and that in untreated section was $35.60 \%$ and $37.01 \%$ (Table 19). The treated section helped in recharging the ground water considerably.

Table 19: Run-off recorded in the watershed area during 2003 and 2004

\begin{tabular}{|c|c|c|c|}
\hline Parameters/Years & Rainfall & $\begin{array}{c}\text { Treated } \\
\text { section }\end{array}$ & $\begin{array}{c}\text { Un-treated } \\
\text { section }\end{array}$ \\
\hline Total runoff $(\mathrm{mm}) / 2003$ & 120 & $20.70(17.25 \%)$ & $42.70(35.60 \%)$ \\
\hline Total runoff $(\mathrm{mm}) / 2004$ & 362 & $35.00(9.66 \%)$ & $134.00(37.01 \%)$ \\
\hline
\end{tabular}

\section{Rejuvenation of chemically degraded and other degraded} lands

The other major type of degraded lands include saline soils, sodic soils, saline-alkali soils, acidic soils, wind eroded soils, ravines, wind eroded soils, degraded pastures, mined lands, etc also deserve top priorities for their management. A lot of proven measures are available which can be employed wherever these soils exist. However, for time limitations, present paper could not deal in details about the measures for these soils.

\section{References}

1. Doran JW, Coleman DC, Bezdicek DF, Stewart BA eds. Defining Soil Quality for a Sustainable Environment. Special Publication \#34, American Society of Agronomy, Madison, WI, USA, 1994.

2. Gadkary DA. A Manual on Soil Conservation. Department of Agriculture, Government of Maharashtra, Poona, India, 1966.

3. Gupta RK, Sharma RA. Paper presented in Intl. Symp. On Natural Resources Management for a Sustainable Agriculture, 6-10 Feb. Proc. Abst. 28, Indian Soc. Agron, New Delhi, 1990.

4. Gupta RK, Sharma RA. Physical aspects of management of black clay soils on central and peninsular India. Proc. of the Intl. Agricultural Engineering Conference and Exhibition. Bangkok, Thailand, 3-6 December, 1990, 1163-1172.

5. Gupta RK, Sharma RA. Intl. Symp. on Natural Resources Management for a Sustainable Agriculture, Feb. 6-10, New Delhi. Abst. 1990 1(2):28.

6. Gupta RK, Sharma RA. Crop Res. 1994; 8(2):276-282.

7. Gupta RK, Sharma SG, Tembe GP, Tomar SS. JNKVV Res. J. 1978; 12:73-79.

8. Jaggi IK. Ph.D. Thesis. Jawaharlal Nehru Agricultural University, Jabalpur, M.P., Indi, 1975.

9. Kanwar JS, Kampen J, Virmani SM. Management of vertisols for maximised crop production-ICRISAT Experience. In. Vertoisols and Rice Soils. Symp. Papers II, 12th Natl. Congr. Soil Science, New Delhi, 1982, 94118. 
10. Patnaik US, James EV, Chittaranjan S, Ramnath B, Subbayyan R. Annual Report of CSWCRTI, Dehradun, 1982, 104-107.

11. Prem Singh, Dr. Hari Charan Behera, Ms. Aradhana Singh (Eds). "Impact and Effectiveness of "Watershed Development Programmes in India" - A Review and Analysis Based on the Studies Conducted by Various Government Agencies", Centre for Rural Studies, National Institute of Administrative Research, Lal Bahadur Shastri National Academy of Administration, Mussouries-248179

12. Ranade DH, Sharma RA. Impact of Indo-UK Operational Research Project (Jamburdi-Hapsi Watershed, 1975-84) on Agricultural Productivity. A Chapter No. 4, P.39-57 in "Impact of Waterashed Development Programme in India" (Om Prakash, G. Sastry and Y.V.R. Reddy, 2004) Published by International Book Distributors, 9/3, Rajpur Road, Dehradun, 248001, Uttaranchal, 2004, 256.

13. Rajendra Prasad, Pathak PS (Eds). "Degraded and Wastelands of India Status and Spatial Distribution" Cocoordinating Editors Virmani SM, Rajendra Prasad, Pathak PS, NAAS, New Delhi, Published by Dr. T P Trivedi, Project Director, Directorate of Information and Publications of Agriculture, ICAR, Krishi Anusandhan Bhavan I, Pusa, New Delhi 110 012, 2010.

14. Sharma RA, Ranad DH. Watershed Development Programme for Conservation of natural resources and Enhancing Productivity of rainfed Crops in Western Madhya Pradesh. A Chapter No. 3, P.21-38 in "Impact of Watershed Development Programme in India" (Om Prakash, G. Sastry and Y.V.R. Reddy, 2004) Published by International Book Distributors, 9/3, Rajpur Road, Dehradun, 248001, Uttaranchal, 2004, 256.

15. Sharma RA. Ph.D. Thesis, Jawaharlal Nehru Agricultural University, Jabalpur, M.P., India, 1976.

16. Sharma RA, Gupta RK. Indian J Soil Conserv. 1984; 12(1):49-57.

17. Sharma RA, Gupta RK. Annual Report, Indo-US Project, AICRPDA, College of Agriculture, Indore, M.P., India, 1990-96.

18. Sharma RA, Upadhyay MS, Tomar RSS. J Indian. Soc. Soil Sci. 1985a; 33:387-391.

19. Sharma RA, Verma GP, Gupta RK. J Indian Soc. Soil Sci. 1985b; 33:383-386.

20. Sharma RA, Gupta RK. Conservation of soil moisture through crop residues management and cultural practices for rainfed agriculture. Proceedings Intl. Symp. on Water Erosion, Sedimentation, and Resource Conservation. October 9-13, 1990. CSWCRTI, Dehradun 248195 (U.P.), India, 1990, 233-243.

21. Sharma RA. Crop Res. 1992; 5:52-58.

22. Sharma RA, Gupta RK. Recent Advances in Dryland Agriculture (Ed L.L. Somani 1983). Scientific Publishers Jodhpur, Rajasthan, India, 1993, 4111-420.

23. Sharma RA. Integrated land and water management practices for sustained and secured productivity of rainfed Vertisols in central and peninsular India. Proc. Ntl. Symposium on Food and Nutritional SecurityTechnological Interventions and Genetic Options, Jointly organized by CSK HPAU, Palampur and SSARM at Palampur during September 18-19. 2003; 2:128-134.

24. Sharma RA, Sharma Nilesh. "Strategies for mitigation of drought effects through resources management practices including indigenous rural technologies with special reference to Madhya Pradesh: A review". International
Journal of Chemical Studies, www.chemijournal.com. (Part-B), Year: 2019; 7(2):137-149.

25. Singh RP. Indain J Dryland Agric. Res. And Dev. 1988; 2:12-16.

26. Suresh Kumar. In: fifty years of Dryland Agricultural Research in India (Eds. Singh HP, Ramakrishna YS, Sharma KL, Venkanteswarlu B). CRIDA, Hyderabad, 1999, 57-72.

27. Verma GP. Proc. of the South East Asian Regional Symposium on Problems of Soil Erosion and Sedimentation. Jan. 27-29, Bangkok, Thailand, 1981, 301310.

28. Verma GP, Raje SR. In. Improving the Management of India's Deep Black Soils, ICRISAT, Patancheru, Hyderabad, A.P., India, 1981, 93.

29. Wani SP, Rego TJ (Eds.) Proc. of the Traveling Workshop-cum-Field Visit to Benchmark Watersheds, 27 August to 12 September 2000. Patancheru 502 324, Andhra Pradesh, India: ICRISAT, 2001, 88.

30. Yadav JSP, Singh GB (Eds.). International Conference on Managing Natural Resources for Sustainable Agricultural Production in the $21^{\text {st }}$ Century. Alpha Printers, WZ-141, NR Road, New Delhi, 2000, 1022. 